\title{
Managing obligations to society. Case of best ranked universities in social responsibility
}

\author{
Carmen PĂUNESCU \\ The Bucharest University of Economic Studies, Bucharest, Romania \\ carmen.paunescu@ase.ro \\ Oana GĂUCĂ \\ The Bucharest University of Economic Studies, Bucharest, Romania \\ Denisa DRĂGAN (GILMEANU) \\ The Bucharest University of Economic Studies, Bucharest, Romania
}

\begin{abstract}
Universities have always been engines for the economy, in multiple roles they play, trying to adapt to the continual dynamic changes in the environment, to better align their offerings with the current expectations of the students, employers and society as a whole. Many of the jobs that are now developing on the market and still will develop, as well as the multiple roles that the graduates are asked to play in society, have never been on the agenda of the universities in the past, nor on the mind of the curriculum designers. The current paper aims to assess the university engagement with community by analyzing 27 world universities best ranked in social responsibility according to QS Stars University Ratings 2016. In the paper, we discuss the extent to which different attributes of the university social responsibility are reflected among the initiatives and projects run by the universities investigated. Also, we analyze correlations between university ranking in social responsibility and other rankings. Following the QS Stars methodology, the criteria used to evaluate social responsibility of selected universities included: community investment and development, social work and service in community, human capital development, environmental concern and impact, and other social responsibility actions. The results show that the degree of involvement of universities in social responsible initiatives varies broadly for each one of the dimensions analyzed, in terms of nature, intensity and impact of initiatives. Our research findings offer good insights for both universities' leaders and community developers in their joint-efforts to develop and grow a prosperous community.
\end{abstract}

Keywords: social responsibility, university ranking, QS Stars University Ratings, community engagement, community development.

\section{Introduction}

Community development is a process in which people from all levels of the society, either they are governmental authorities, public institutions, private companies, NGOs or civil society, unite their forces to improve living conditions and the wellbeing of their community (Checkoway, 1995). Community development resides in the idea that people share common goals and values that help them develop in the same direction and on common grounds to create the needed change at the community level. Universities can and should have an enormous power in the change map. Like any other organization, universities have to assume their role in the community and act as a change agent necessary to feed community development through knowledge, skills and jobs. By taking a leading role in society, they will contribute to helping communities develop their own way of sustainable growth and development. But moreover, universities have to discover the role that the community in which they are based want them to play. 
The current paper aims to assess the nature and type of university engagement with local communities and global issues by analyzing 27 world universities best ranked in social responsibility according to QS Stars University Ratings 2016. The extent to which different attributes of the university social responsibility are reflected among the initiatives and projects run by the researched universities is discussed. Also, correlations between university ranking in social responsibility and other rankings are analyzed. The paper starts with a review of how university social responsibility has progressively evolved. Then it explains the methodology used to assess the university social responsibility. Finally, analysis is conducted on selected universities and conclusions are drawn based on results.

\section{Literature review}

\section{University's perspective on community engagement}

With the new competition that is faster increasing, universities themselves had to create better connections with the communities where they are based and operate, promoting a more caring social image, and supplying constantly added value to all their stakeholders (Boyle and Silver, 2005; Păunescu and Cantaragiu, 2013). By doing so, many universities have developed partnerships with various actors from the socio-economic environment, have invested in R\&D centers and community hubs that promote social responsibility and develop worldwide community impact projects and, of course, have developed themselves as a more powerful actor on the social map.

Engagement from a university's perspective is everything that is important for the community, to change mentalities, attitudes and ways in which things are done, and to create collaboration between the social, economic and academic actors. This engagement comes from universities through their students, academic faculties and institutions as a whole and takes different forms, like ideas, information, knowledge, research, feedback, technical assistance and support. No real social problem can be solved or even understood without these two groups working together.

Formal collaborations between community groups and academic institutions to promote economic development have increased substantially over the past 10 years. The bulk of research on community-campus partnerships has focused more on the experiences of universities, leaving a gap in the real understanding of community experiences (Afshar, 2005). There has also been a strong emphasis on partnerships or relations that the universities can develop with the outside world, that lead to knowledge creation and a beneficial exchange (Muller and Subotzky, 2001; Mtawa et al., 2016).

Community development as the third mission of the university has been central in any higher education discourse for many years (Benneworth and Sanderson, 2009; Farrar and Taylor, 2009; Kruss, 2012). However, the concept is debated and defined differently by various scholars. Some view it as a university's service to the community, by knowledge dissemination (Weerts and Sandmann, 2008), while others perceive community engagement to be part of the entrepreneurial initiative of the universities, that can bring extra income during times of financial difficulty (Clark, 1998). Also, this term has replaced various other different terminologies used for the same scope, like for example outreach, extension or service (Bender, 2008).

Community-academic partnerships and other forms of university engagement in community can be difficult, and there are many reports exploring the dynamics of such developments (e.g., Hammersley, 2013). Absent from the literature, however, are 
systematic assessments of how academia actually involves community in their research and projects, what works, what doesn't, and how the nature of the projects influence how communities are involved and will evolve (Sullivan et al., 2001; Goldberg-Freeman et al., 2010).

\section{Methodology}

To achieve its main goal, the paper has three specific objectives: (1) understanding if there is any correlation between ranking in social responsibility and ranking in employability and inclusiveness; (2) determining the extent to which a good ranking in social responsibility contribute to a better overall ranking of university, and (3) understanding the type of social responsibility actions in which the universities invest. Thus, 27 world universities, best ranked in social responsibility according to QS Stars University Ratings 2016, have been selected out of the 41 universities ranked in the 5 star category. We used as criteria for selection geographical representation of university across all over the world and its presence in both employment and inclusiveness rankings.

For this purpose, we used the QS Stars University Rating 2016 database to select the universities that make the object of current research. QS Stars is a rating system which allows students, academics or institutions themselves to get a wider picture of a university's qualities. The following criteria form the basis for QS Stars University Ratings: research, teaching, employability, internationalization, facilities, online/ distance learning, social responsibility, innovation, arts and culture, inclusiveness, specialist criteria. Institutions are evaluated against over 50 different indicators and successfully awarded between one and $5+$ stars over five wider fields, as well as an overall rating. In the paper we analyze only the university commitment and obligations to society. Following the QS Stars methodology, social responsibility of universities is assessed against the following criteria: community investment and development, charity work and disaster relief, regional human capital development, environmental impact, and other social responsibility actions. These criteria made the object of our research.

\section{Results and discussion}

\section{Analysis of universities ratings and rankings}

According to QS Stars University Ratings 2016, there are 88 universities ranked in social responsibility (SR) relative to 195 listed in overall ranking (OR), 171 in employment (E) and 155 in inclusiveness (I) (Table 1). Also, 36.41\% $(n=71)$ of the universities listed in overall ranking are 5 stars and 5 starts+ universities, 46.59\% $(n=41)$ are 5 stars universities in social responsibility, $57.89 \%(n=99)$ in employment and $78.70 \% \quad(n=122)$ in inclusiveness. While social responsibility measures how seriously a university takes its obligations to society by investing in the local communities and addressing global issues, employment encompasses graduates' work-readiness and inclusiveness looks at university commitment to extending access to higher education.

Table 1. University ratings in different dimensions according to QS Stars University Ratings 2016.

\begin{tabular}{lccccccc}
\hline & \multicolumn{8}{c}{ No. of universities in each star category } \\
\hline Criteria & Total & $\mathbf{5 ~ s t a r s +}$ & $\mathbf{5}$ stars & 4 stars & 3 stars & 2 stars & 1 star \\
\hline Overall ranking (OR) & $\mathbf{1 9 5}$ & 17 & 54 & 39 & 59 & 25 & 1 \\
\hline Social responsibility (SR) & $\mathbf{8 8}$ & - & 41 & 9 & 20 & 7 & 11 \\
\hline Employment (E) & $\mathbf{1 7 1}$ & - & 99 & 29 & 24 & 16 & 3 \\
\hline
\end{tabular}


When looking at the frequencies with which the universities ranked in social responsibility and rated at 4-5 stars are found in other rankings, respectively overall ranking, employment and inclusiveness (and the same ratings 4-5 stars) we observe different levels of correlation between those rankings (Table 2). Thus, $24.39 \%(n=10)$ of the 5 stars universities ranked in social responsibility are also listed in overall ranking (low correlation), 65.85\% $(\mathrm{n}=27)$ are also ranked in employment (moderate high correlation) and $63.41 \%(n=26)$ in inclusiveness (moderate high correlation). Also, $11.11 \%(n=1)$ of the 4 stars universities ranked in social responsibility are listed in overall ranking (low correlation), 44.44\% $(n=4)$ are also ranked in employment and $44.44 \%(n=4)$ in inclusiveness (moderate correlation). The trend lines manifested for the other universities are slightly changing and follow the same direction. As such, there is no correlation between ranking in social responsibility and overall ranking for 3,2 and 1 stars universities, low to medium correlation between ranking in social responsibility and ranking in employment and low to medium correlation between ranking in social responsibility and ranking in inclusiveness (same star categories).

Table 2. Frequency with which QS Stars universities ranked in social responsibility are found in other QS Stars rankings.

\begin{tabular}{|c|c|c|c|c|c|c|c|}
\hline \multirow[b]{2}{*}{$\begin{array}{l}\text { Social responsibility } \\
\text { rating }\end{array}$} & \multirow[b]{2}{*}{ Criteria } & \multicolumn{6}{|c|}{ No. of universities in each star category } \\
\hline & & Total & $\begin{array}{c}5 \\
\text { stars }\end{array}$ & $\begin{array}{c}4 \\
\text { stars } \\
\end{array}$ & $\begin{array}{c}3 \\
\text { stars } \\
\end{array}$ & $\begin{array}{c}2 \\
\text { stars }\end{array}$ & $\begin{array}{c}1 \\
\text { star }\end{array}$ \\
\hline \multirow{3}{*}{$\begin{array}{c}5 \text { stars: } 41 \text { universities } \\
\text { out of which: }\end{array}$} & Overall ranking & 39 & 10 & 9 & 19 & 1 & - \\
\hline & Employment & 39 & 27 & 8 & 3 & 1 & - \\
\hline & Inclusiveness & 31 & 26 & 4 & 1 & - & - \\
\hline \multirow{3}{*}{$\begin{array}{c}4 \text { stars: } 9 \text { universities } \\
\text { out of which: }\end{array}$} & Overall ranking & 9 & 1 & 1 & 4 & 3 & - \\
\hline & Employment & 9 & 4 & 2 & 2 & 1 & - \\
\hline & Inclusiveness & 6 & 4 & 1 & 1 & - & - \\
\hline \multirow{3}{*}{$\begin{array}{c}3 \text { stars: } 20 \text { universities } \\
\text { out of which: }\end{array}$} & Overall ranking & 20 & - & 6 & 9 & 5 & - \\
\hline & Employment & 19 & 8 & 3 & 2 & 5 & 1 \\
\hline & Inclusiveness & 14 & 11 & 2 & 1 & - & - \\
\hline \multirow{3}{*}{$\begin{array}{c}2 \text { stars: } 7 \text { universities } \\
\text { out of which: }\end{array}$} & Overall ranking & 7 & - & - & 3 & 4 & - \\
\hline & Employment & 6 & 1 & 1 & 2 & 1 & 1 \\
\hline & Inclusiveness & 5 & 4 & 1 & - & - & - \\
\hline \multirow{3}{*}{$\begin{array}{c}1 \text { star: } 11 \text { universities } \\
\text { out of which: }\end{array}$} & Overall ranking & 11 & - & 3 & 5 & 3 & - \\
\hline & Employment & 11 & 3 & 2 & 3 & 2 & 1 \\
\hline & Inclusiveness & 7 & 2 & 2 & 2 & 1 & - \\
\hline
\end{tabular}

Source: Authors' own research.

Based on the correlations identified between those rankings, we selected a list of 27 universities, which are further analyzed in the paper (Table 3). We observe that, out of the 27 universities, $92.59 \%(n=25)$ are rated as 5 stars in social responsibility, $85.18 \%(n=23)$ are rated as 5 stars in employment, $66.66 \%(n=18)$ are 5 stars in inclusiveness and 37.03\% $(n=10)$ in overall ranking. Also, out of the $25(100 \%) 5$ stars universities in social responsibility, $84.0 \%(n=21)$ are 5 stars in employment, 64.0\% $(n=16)$ are 5 stars in inclusiveness and $36.0 \%(n=9)$ are 5 stars in overall ranking. We might conclude that a high ranking in social responsibility is positively correlated with a high ranking in employability. Also, the same positive correlation is found between ranking in social responsibility and ranking in inclusiveness, but not of the same tie. Furthermore, there is a weak correlation 
between ranking in social responsibility and overall ranking of universities, which means that other criteria contribute more to the global ranking of universities.

Table 3. List of analyzed universities and their ratings in different rankings.

\begin{tabular}{|c|c|c|c|c|c|}
\hline \multirow[b]{2}{*}{ Country } & \multirow[b]{2}{*}{ University } & \multicolumn{4}{|c|}{ Ratings (no. of stars) } \\
\hline & & SR & OR & $\mathbf{E}$ & I \\
\hline \multirow{3}{*}{$\begin{array}{c}\text { Australia } \\
\text { (3) }\end{array}$} & Bond University & 5 stars & 5 stars & 5 stars & 5 stars \\
\hline & RMIT University & 5 stars & 5 stars & 5 stars & - \\
\hline & University of South Australia & 5 stars & 5 stars & 5 stars & 5 stars \\
\hline \multirow{3}{*}{$\begin{array}{c}\text { Brazil } \\
\text { (3) }\end{array}$} & Centro Universitario Ritter dos Reis & 5 stars & 3 stars & 5 stars & 5 stars \\
\hline & Universidade Anhembi Morumbi & 5 stars & 3 stars & 5 stars & 5 stars \\
\hline & Universidade Salvador & 5 stars & 3 stars & 5 stars & 5 stars \\
\hline $\begin{array}{l}\text { Chile } \\
\text { (1) }\end{array}$ & Universidad Andres Bello & 5 stars & 4 stars & 5 stars & 5 stars \\
\hline $\begin{array}{l}\text { Cyprus } \\
\text { (1) }\end{array}$ & European University Cyprus & 5 stars & 4 stars & 4 stars & 5 stars \\
\hline \multirow{2}{*}{$\begin{array}{c}\text { Indonesia } \\
(2)\end{array}$} & Bina Nusantara University & 5 stars & 3 stars & 5 stars & 5 stars \\
\hline & Universitas Islam Indonesia & 5 stars & 3 stars & 5 stars & 5 stars \\
\hline \multirow{2}{*}{$\begin{array}{l}\text { Ireland } \\
(2)\end{array}$} & University College Cork & 5 stars & 5 stars & 5 stars & - \\
\hline & University of Limerick & 5 stars & 5 stars & 5 stars & - \\
\hline \multirow{2}{*}{$\begin{array}{l}\text { Mexico } \\
(2)\end{array}$} & Universidad de Monterrey & 5 stars & 4 stars & 5 stars & 4 stars \\
\hline & Universidad del Valle de Mexico & 5 stars & 3 stars & 5 stars & 5 stars \\
\hline $\begin{array}{c}\text { New } \\
\text { Zeeland (1) }\end{array}$ & Massey University & 5 stars & 5 stars & 5 stars & - \\
\hline $\begin{array}{l}\text { Peru } \\
(1)\end{array}$ & $\begin{array}{l}\text { Universidad Peruana de Ciencias } \\
\text { Aplicadas }\end{array}$ & 5 stars & 3 stars & 5 stars & 5 stars \\
\hline $\begin{array}{l}\text { Philippines } \\
\text { (1) }\end{array}$ & University of Santo Tomas & 5 stars & 4 stars & 5 stars & 5 stars \\
\hline $\begin{array}{l}\text { Singapore } \\
(1)\end{array}$ & Singapore Management University & 4 stars & 5 stars & 5 stars & 5 stars \\
\hline $\begin{array}{l}\text { Spain } \\
(1)\end{array}$ & Universidad Europea & 5 stars & 4 stars & 5 stars & 4 stars \\
\hline $\begin{array}{l}\text { Thailand } \\
\text { (1) }\end{array}$ & Thammasat University & 5 stars & 4 stars & 5 stars & 5 stars \\
\hline $\begin{array}{l}\text { Turkey } \\
\text { (1) }\end{array}$ & Istanbul Bilgi Universitesi & 5 stars & 3 stars & 5 stars & 5 stars \\
\hline \multirow{3}{*}{$\begin{array}{l}\text { UK } \\
\text { (3) }\end{array}$} & Northumbria University at Newcastle & 4 stars & 4 stars & 5 stars & 5 stars \\
\hline & Nottingham Trent University & 5 stars & 4 stars & 4 stars & 5 stars \\
\hline & University of Central Lancashire & 5 stars & 4 stars & 5 stars & 5 stars \\
\hline \multirow{3}{*}{$\begin{array}{l}\text { USA } \\
(3)\end{array}$} & Harvard University & 5 stars & 5 stars & - & - \\
\hline & University of Michigan & 5 stars & 5 stars & 5 stars & - \\
\hline & University of Pennsylvania & 5 stars & 5 stars & - & - \\
\hline
\end{tabular}

Source: Authors' own research.

\section{Analysis of criteria used to measure universities' social responsibility}

Developing the local, regional, even national communities is often central to a university's mission. This is a two-way process and both society and university itself should mutually benefit from this collaboration.

The following criteria have been used in the paper to understand the type of social responsibility actions a university invests in and how it measures its progress: (a) Community investment and development, understood as benefits (both financial and intangible gains) gained by communities in which university is based or operates as well as by university that is part of modern community; (b) Social work and service in community, understood as awareness of and interest in supporting charities and social cause campaigns, interest in volunteering, etc.; (c) Human capital development for local/ regional needs, measured by graduates employability rate within the region and proportion of the 
students coming from the region, who will contribute to that region's economic prosperity, and (d) Environmental concern and impact, measured by the nature and intensity of programs that address needs for energy conservation, water conservation, waste minimization, green transportation, recycling, etc. The coming paragraphs summarize various good practices shared by the universities investigated, which can be further taken as useful learning lessons for those universities interested in enhancing their community engagement.

Our analysis reveals that universities create different institutional or professional structures, formal and informal, to deal with community investment and development issues. Thus, there are, for example, community service clubs which enable students to explore specific social issues in depth in their community. Also, there are campus hubs for volunteer and community-engaged learning opportunities, service and social justice focused workshops, and leadership development. Or, there are open spaces that enable students to come together authentically around issues, communities, and beliefs they hold important. Online portals connect students with communities around the world through volunteer experiences as well as internships, fellowships, and employment.

When it comes to community development, universities invest in various community projects facilitated by the on-campus clubs and societies, students' associations, as well as the individual academic faculties. These activities include, for example, running IT and foreign language classes, running children's sports programs, performing maintenance on hospitals, schools or other places which need revitalization, assisting with the development and marketing of a nutrient-rich food which is manufactured locally, organizing fundraising campaigns for the local schools, shelters, or orphanages.

Universities contribute also to community service through various charitable initiatives that have as goals, for example, to assist families' access early intervention treatment or to raise awareness of animals suffering in factory farming or to provide quality and adequate housing for the disadvantaged at a reasonable rental.

To what concerns the human capital development, beyond the formal training and education, universities offer careers services hub, covering everything from career planning to internships, work experience placements, part-time jobs and graduate destinations. Also, in addition to the formal student project work available to organizations through clientbased classes, organizations are offered the help of individual students and student teams through paid, mentored internships on community impact projects. Students typically work on information-related projects that organizations don't have the in-house skills, resources, or time to accomplish. Organizations generally are non-profits or public-oriented, but other types of organizations are welcomed to participate as well. In this way the students have the opportunity to use their skills to make an impact on their community before they leave the school. Examples of projects include: assessing websites or software for improvements in design and usability, organizing and analyzing large sets of data for better use, instructing youth or underserved populations on technology use or language skills, analyzing information flows and providing recommendations for increased efficiency.

To encourage a sustainable development of the university's campus, universities, through student associations, teams of students and faculty members, run various programs that promote sustainable living among peers. Such programs focus, for example, on green transportation, energy and water conservation, recycling and waste minimization. Thus, some universities offer cyclist facilities with bicycle racks, showers and storage 
lockers which encourage students and staff to ride to campus, reducing vehicle emissions and promoting a healthy lifestyle. Also, classrooms and offices are positioned to minimize the impact of direct sun. Window glass, window shadings and the circulation spine reduce the need for air conditioning and artificial lighting by maximizing natural ventilation and daylight. The use of photovoltaic cells with rooftop solar system is encouraged as well. Furthermore, recyclables can be easily sorted and collected by recycling contractors in the waste storage area, reducing the waste going to landfill. Rainwater is collected, stored in tanks, and used to flush toilets and irrigate the landscape. Grey water from showers and basins is also treated and re-used for irrigation. Empty plastic bottles are easily collected and transformed into fully-functioning surfboards or other products.

Students' school projects address these issues and all parties involved benefit form that. On one hand, community benefits from the new and tightly focused research and development generated for them that meets their needs and, on the other hand, the staff and students benefit as well from direct exposure to 'real world' challenges and professional practice.

Finally, through specialized centers, universities undertake multi-disciplinary applied teaching and research aimed at understanding the impacts of disasters on communities, improving risk management and enhancing community preparedness, response and recovery from various hazard events.

\section{Conclusion}

The paper discusses various measures considered by universities to evaluate their social responsibility. It presents four criteria which measure university engagement to community, namely community investment and development, social work and service in community, human capital development for local/ regional needs, and environmental concern and impact. Particularly, the paper examines how seriously a university takes its obligations to society by investing in the local communities and in different charity work that contribute to development of the area in which they are based and operate. It also analyses contribution of university to the local or regional human capital development. Furthermore, it analyses the extent to which university proves concern and care about environment or other global issues.

Our results suggest that the extent to which universities manifest their social responsibility is strongly correlated with their focus on graduates' employability as well as with university's commitment to accessibility of the university to students. Also, we found that universities that rank high in social responsibility are more likely to rank higher in employability and in inclusiveness. The research findings offer good insights for both universities' leaders and community developers in developing strategies for growing a prosperous community.

\section{References}

Afshar, A. (2005). Community-campus partnerships for economic development: community perspectives. Federal Reserve Bank of Boston, Discussion Papers. Retrieved from http://www.bos.frb.org/commdev/pcadp/2005/pcadp0502.pdf (Accessed on January 10, 2017). 
Bender, G. (2008). Exploring conceptual models for community engagement at Higher Education Institutions in South Africa. Perspectives in Education, 26 (1), 81-95.

Benneworth, P., Sanderson, A. (2009). The regional engagement of universities: building capacity in a sparse innovation environment. Higher Education Management and Policy, 21(1), 1-18.

Boyle, M.E., Silver, I. (2005). Poverty, partnerships, and privilege: Elite institutions and community empowerment. City and Community, 4(3), 233-253.

Clark, R.E. (1998). Supported employment and managed care: Can they coexist? Psychiatric Rehabilitation Journal, 22(1), 62-68.

Checkoway, B. (1995). Six strategies of community change. Community Development Journal, 30, 2-20.

Farrar, M., Taylor, R. (2009). University-community engagement. In: Denton, S., Brown, S. (Eds.), A Practical Guide to University and College Management. Beyond Bureaucracy, Routledge, New York, 247-265.

Goldberg-Freeman, C., Kass, N., Gielen, A.C., Farfel, M. (2010). Faculty beliefs, perceptions, and level of community involvement in their research: A survey at one urban academic institution. Journal of Empirical Research on Human Research Ethics, 5(4), 65-76.

Hammersley, L. (2013). Community-based service-learning: Partnerships of reciprocal exchange? Asia-Pacific Journal of Cooperative Education, 14(3), 171-184.

Kruss, G. (2012). Reconceptualising engagement: a conceptual framework for analyzing university interaction with external social partners. South African Review of Sociology, 43(2), 5-26.

Mtawa, N.N., Fongwa, S.N., Wangenge-Ouma, G. (2016). The scholarship of universitycommunity engagement: Interrogating Boyer's model. International Journal of Educational Development, 49(C), 126-133.

Muller, J., Subotzky, G. (2001). What knowledge is needed in the new millennium? Organization, 8(2), 163-182.

Păunescu, C., Cantaragiu, R. (2013). The Social Role of University Entrepreneurship. In "Strategic Role of Tertiary Education and Technologies for Sustainable Competitive Advantage". IGI Global, 103-119.

Sullivan, M., Kone, A., Senturia, K.D., Chrisman, N.J., Ciske, S.J., Krieger, J.W. (2001). Researcher and researched-community perspectives: Toward bridging the gap. Health Education \& Behavior, 28(2), 130-149.

Weerts, D.J., Sandmann, L.R. (2008). Building a two-way street: challenges and opportunities for community engagement at Research Universities. Review of Higher Education, 32(1), 73-106. 